[Agr. Biol. Chem., Vol. 27, No. 6, p. 469 470, 1963]

\title{
Microbial Formation of Nucleotides
}

Brawerman and Chargaff'), in 1955, demonstrated the distribution of nucleoside phosphotransferase activity in plants, mammal tissues and two strains of bacteria. The results obtained therein about the phosphate transfer reaction indicated that in mammal tissues 3' (\& 2')-nucleotide was formed together with 5'-isomer, while in plants and bacteria only $5^{\prime}$-isomer was formed.

In the course of our experiments on the microbial formation of nucleotides, it appeared that the phosphotransferases were distributed widely in various kinds of microorganisms and that the nucleotides formed by their enzymes were not always 5'-isomer. The results obtained from the phosphorylation of adenosine, for an example as shown in Expt.
I of Table I, indicated that some strains of bacteria formed $5^{\prime}$-adenylic acid alone, while the others formed $3^{\prime}\left(\& 2^{\prime}\right)$-isomer together with a small amount of 5 '-isomer. Most of the other kinds of nucleosides were also phosphorylated in the same way as was mentioned with adenosine. These findings contrast with the observation of Brawerman and Chargaff, as was described above.

In a large scale experiment, the reaction mixture containing $400 \mu$ moles of inosine, $1400 \mu$ moles of disodium $p$-nitrophenylphosphate, $20 \mu$ moles of cupric sulfate and $40 \mathrm{mg}$, as dry matter, of resting cells of Pseudomonas melanogenum $(\mathrm{F}-11)$ in a total volume of

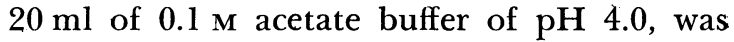
incubated for 24 hours at $37^{\circ} \mathrm{C}$. At this stage,

TABle I. Phosphorylation of Adenosine AND INOSINE By Bacteria

Expt.

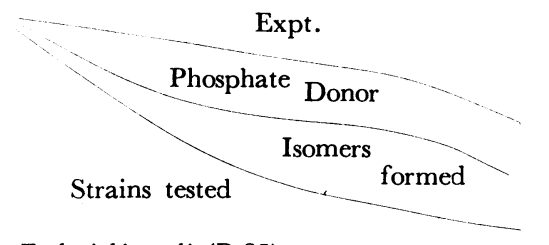

Escherichia coli (B-25)

Aerobacter aerogenes (ATCG 8329)

Proteus mirabilis (OM-9)

Staphylococcus citreus (ATCG 4012)

Flarobacterium harrisonii (NO. 1161)

Pseudomonas perlurida (IAM 1600)

Serratia marcescens (F-420)

* NPP : $p$-Nirrophenylphosphate.

** 5'-CMP : 5'-Cytidylic acid.

*** $3^{\prime}\left(\& 2^{\prime}\right)$-CMP : $3^{\prime}\left(\& 2^{\prime}\right)-C y t$-Cidylic acid.

In Expt. I, the reaction mixture containing, per $\mathrm{ml}$ of $0.1 \mathrm{~m}$ acetate buffer of $\mathrm{pH} 4.0,20 \mu$ moles of adenosine, $70 \mu \mathrm{moles}$ of disodium $p$-nitrophenylphosphate, $1 \mu$ mole of cupric sulfate and $2 \mathrm{mg}$ of resting cells as dry matter, was incubated for 24 hours at $37^{\circ} \mathrm{C}$.

In Expt. II, the rcaction mixture containing, per $\mathrm{ml}$ of $0.1 \mathrm{~m}$ acetate buffer of $\mathrm{pH} 4.0,20 \mu$ moles of inosine, $36 \mu \mathrm{moles}$ of $5^{\prime}-$ or $3^{\prime}\left(\& 2^{\prime}\right)$-cytidylic acid, $1 \mu \mathrm{mole}$ of cupric sulfate and $3 \mathrm{mg}$ of resting cells as dry matter, was incubated for 3 hours at $37^{\circ} \mathrm{C}$.

Adcnylic acids formed were determined spectrophotometrically after being separated by anion-exchange chromatography (Dowex-1X4, formate form $)^{2)}$. Inosinic acids formed were also determined spectrophotometrically after being separated by paper chromatography with aqueous isobutyric acid buffered with ammonium isobutyrate ${ }^{2)}$.

1) G. Brawerman and E. Chargaff, Biochim. Biophys. Acta, 16, 524 (1955).
2) B. Magasanik, E. Vischer, R. Doniger, D. Elson and E. Chargaff, I. Biol. Chem., 186, 37 (1950). 
$43 \%$ of $p$-nitrophenylphosphate added were found to be decomposed and $260 \mu$ moles of inosinic acid were formed. The inosinic acid was isolated by anion-exchange chromatography3) and was identified to be $5^{\prime}$-isomer by snake venom $5^{\prime}$-nucleotidase and by the method of metaperiodate oxidation ${ }^{4}$.

Moreover, when the nucleotides were used as phosphate donors, the phosphorous group of them were specifically transferred to the same position of the nucleotide which were produced by the bacteria, as shown in Expt. II of Table $\mathrm{I}$.

From these experiments, it seems most probable to conclude that the bacteria which can form nucleotides by their phosphotransferase activities are divided into two groups, based on the kinds of nucleotide-isomers formed and the donor specificity. Bacteria of the first group were found in such genera as Flavobacterium. Serratia, Pseudomonas, Achromobacter and Staphylococcus and produce mainly 5'-nucleotide, while relatively large amounts of $3^{\prime}\left(\& 2^{\prime}\right)$-isomer together with a small amount of $5^{\prime}$-isomer are produced by

3) W.E. Cohn and E. Volkin, Nature, 167, 483 (1951).

4) J.S. Dixon and D. Lipkin, Anal Chem., 26, 1092 (1954). the second group of bacterial strains assigning to such genera as Escherichia, Aerobacter, Aeromonas, Proteus and Salmonella.

It is, therefore, considered that such microorganisms of the first group must be selected as the enzyme source to prepare the $5^{\prime}$-isomer of nucleotide from a nucleoside and a phosphate donor.

The authors are indebted to Dr. H. Iizuka of the Institute of Applied Microbiology, Tokyo University, and Dr. K. Aiso of the Institute of Food Microbiology, Chiba University, for kind supplies of bacterial strains and to Dr. H. Ôeda, Mr. S. Motozaki, Dr. Y. Tsuchiya, Dr. T. Tsunoda, Dr. K. Komagata and Dr. S. Okumura of our laboratory for their interest and encouragement during the course of this work.

\section{Hideo KATAGIRI* \\ Hideaki YAMADA* \\ Kôji Mitsugi \\ Masahiro TAKAHASHI}

Department of Agricultural Chemistry,

Kyoto University, Kyoto.*

Central Research Laboratory of

Ajinomoto Co. Inc., Kawasaki

Received April 8, 1963 